\title{
Valtio-opin monet yhteisöt
}

ANNU PERÄLÄ

Valtio-opin satavuotismerkkivuotta juhlittiin lokakuun puolessa välissä Politiikka-lehden järjestämässä tilaisuudessa "Valtio-opin vuosikymmenet - Tarinoita kuvien takaa". Juhlassa kuusi politologia eri ikäpolvista ja eri puolilta Suomea jakoi muistonsa tai ajatuksensa valtio-opin opiskelusta, tutkimuksesta ja opettamisesta. Puheenvuorojen ja keskustelun punaiseksi langaksi muodostui yhteisöllisyys.

\section{VALTIO-OPPI YHTEISÖNÄ}

Valtio-opin yhteisö on hajaantunut ympäri Suomen yhteensä kuuteen yliopistoon. Ensimmäiset erot syntyvät jo siinä, miten valtio-oppi sijoittuu kulloisenkin yliopiston organisaatiokarttaan ja miksi oppialaa ylipäänsä nimitetään. Paikallisilla politiikan tutkimuksilla on myös omat vahvat painotuksensa niin tutkimusaiheiden kuin -menetelmien suhteen. Vaikka monet perinteiset tutkimuskohteet, kuten äänestäminen, pitävät yhä pintansa, on politiikan tutkimuksen aihekirjo aiempaa moninaisempi.

Uudet näkökulmat ja tutkimustavat avaavat uusia katsantokantoja alati muuttuviin yhteiskuntiin. Samalla ne johtavat valtio-opin jonkinasteiseen silloutumiseen, pahimmillaan jopa nurkkakuntaisuuteen. Monitieteisyyttä korostavassa projektimaailmassa yhteistyökumppanit löytyvät usein lähimpiä kollegoita lukuun ottamatta politiikan tutkimuksen ulkopuolelta.

- Monitieteisyys on tärkeää, mutta niin ovat myös syvät juuret omaan tieteenalaan. Vaikka välillämme on eroja, meillä on myös paljon yhteistä, päätoimittaja Katja Mäkinen sanoo ja jatkaa:

- Politologeja yhdistää kiinnostus sitä kohtaan, mitä valta, politiikka ja poliittisuus ovat. Yhteistä on myös kriittinen ja kyseenalaistava tarkastelutapa.

Kahnauksiakin kuitenkin syntyy. Syrjivä ja vähättelevä suhtautuminen toisten tutkijoiden lähestymistapoihin ei ole tuntematonta valtio-opinkaan sisällä. Yksi pitkäaikaisemmista kiistoista on koskenut kvantifioinnin ja tulkinnallisempien lähestymistapojen vastakkainasettelua.

- Toivon, että kvantifiointi on nykyisin käypä menetelmä tutkimuksen teossa, mutta että se ei vapauta ketään tulkinnallisten ongelmien pohtimiselta, professori emerita Marja Keränen Jyväskylän yliopistosta summaa.

\section{YHTEISÖT YHTEISÖN SISÄLLÄ}

Maantieteellisesti hajanaisen ja tutkimusotteiltaan moninaisen valtio-opin tutkijayhteisön sisältä löytyy tarkkarajaisempia yhteisöjä, jotka kannattelevat monia, itsestään selviksikin miellettäviä 
yhteisöllisiä toimintoja. Yhdistysasiat, tieteellinen ja populaari julkaisutoiminta ja yliopistomaailman sisäinen edunvalvonta ovat kaikki politologien oman aktiivisuuden tuotteita.

- Esimerkiksi Politiikka-lehti ei ilmesty automaattisesti, vaan sen takaa löytyy yhteisöjä, jotka tuottavat sitä, päättäjiä, jotka rahoittavat sitä ja aktiivisia ihmisiä, jotka käytännössä vievät lehteä eteenpäin, yliopistotutkija ja Valtiotieteellisen yhdistyksen puheenjohtaja Emilia Palonen Helsingin yliopistosta valaisee.

Akateemisen maailman kiristyvässä työtahdissa yhteisön sisäiset vastuutehtävät voivat kuitenkin näyttäytyä taakkana. Pisimmälle uralleen ehtineillä on jo valmiiksi paljon muitakin vastuutehtäviä, kun taas nuoremmat tutkijat paiskivat pitkää päivää turvatakseen elantonsa myös jatkossa.

- Yliopistomaailma on muuttunut siten, että tärkeisiin kollegiaalisiin vastuutehtäviin on aiempaa vaikeampaa löytää aikaa ja sitä kautta ihmisiä. Oman tutkimuksen eteenpäin saattaminen ja rahoituksen turvaaminen ovat ylitsepääsemätön huoli oman ikäisteni tutkijoiden keskuudessa, tutkijatohtori ja Politiikasta-verkkojulkaisun päätoimittaja Mikko Poutanen Tampereen yliopistosta kertoo.

Vaikka yliopiston työskentelyolosuhteiden parantamiseen ei näytä olevan helppoja ja nopeita ratkaisuja, pitävät tutkijat arjen vaikeita asioita esillä myös yliopiston päättävissä elimissä. Kokemukset yliopistojen ulkopuolelta tulevien hallituskumppaneiden kiinnostuksesta ja arvostuksesta kriittisiä näkökulmia kohtaan ovat ainakin osin rohkaisevia.

\section{TUTKIMUSTA YHTEISÖISTÄ}

Politiikan tutkimuksen keskiössä on kysymys vallasta. Perinteinen käsitys paikantaa vallan virallisiin vallan instituutioihin, jotka muodostavatkin keskeisen - ja yhä erittäin merkittävän - valtio-opillisen tutkimuskohteen. Valtaa on kuitenkin kaikissa inhimillisissä yhteisöissä, ja myös osa politiikan tutkijoista on suunnannut katseensa arkisempiin yhteenliittymiin ja niiden marginaaleihin.

Yhteisöjen tutkimus tarkoittaa usein tutkijan uudenlaista, läheisempää suhdetta tutkimuskohteisiinsa. Läheisyys tutkimuskohteiden kanssa voi kuitenkin poikia myös omia haasteita ja jännitteitään.

- Olen tehnyt etnografista tutkimusta Käsivarren Lapissa ja osallistunut poronhoitotöihin. Nyt minusta tuntuu, että poronhoitajayhteisö on tutkimuksen kannalta liiankin läheinen. On hyvä ottaa etäisyys ja tauko, ja miettiä, miten voi tutkijana palata itselle läheiseen yhteisöön niin, että myös tutkimus kestää kriittisen tarkastelun, yliopistonlehtori Tapio Nykänen Lapin yliopistosta pohtii.

Åbo Akademin professori Kim Strandberg on tehnyt kenttätutkimusta, jossa deliberatiivisen demokratian teoriaa kokeillaan käytännössä. Tapausesimerkkinä toimi kansalaiskeskustelu suunnitelmasta liittää Mustasaaren kunta Vaasaan. Aihe oli paikallisesti tulenarka ja osa asukkaista suhtautui tutkijoihin ennakkoluuloisesti.

- Aineistonkeruu ja tutkimuksenteko olivat antoisaa ja opettavaista, mutta myös haastavaa, työlästä ja raskasta. Yksi tärkeä selviytymisstrategia oli sisäinen vertaistuki. Me tutkijat tapasimme toisiamme säännöllisesti ja jaoimme kokemuksia, myös muissa yliopistoista työskentelevien tutkijoiden kanssa, Strandberg selittää. 


\section{TIEDE ON YHTEISÖLLISTÄ TOIMINTAA}

Arjen kiireissä valtio-oppi voi näyttäytyä hajanaisena yhteisönä, jonka sisällä eri ryhmittymät osallistuvat omien erityisalojensa konferensseihin ja tapaavat toisiaan korkeintaan Politiikan tutkimuksen päivillä. Huonoimpina päivinä valtio-opin yhteisölliset vastuutehtävät näyttäytyvät pelkiltä taakoilta. Koventuvassa akateemisessa kilpailussa yhteisöllisyydelle jää aikaisempaa vähemmän henkisiä, materiaalisia ja ajallisia resursseja, vaikka samalla se olisi kenties aikaisempaakin merkityksellisempää ja tarpeellisempaa. Erityisesti yhteisön sisäinen kannustus ja vertaistuki saisivat lisääntyä tulevaisuudessa.

Samalla on hyvä muistaa, että tiede on aina läpeensä yhteisöllistä. Tiede rakentuu sen ympärille, että luemme toistemme tekstejä, kommentoimme niitä - ja opimme. Mikään tieteellinen tuotos ei synny ilman yhteisöä.

- Toisilta oppiminen on yksi kaikkein arvokkaimmista opeista, jonka olen saanut yliopistoopintojeni aikana. Minulle valtio-oppi on näyttäytynyt vuorovaikutuksena, se on keskustelua ja oppimista ammattilaisilta ja muilta opiskelijoilta. Se ei ole vain yksin pänttäämistä - vaan yhteisö, toisen vuoden opiskelija Seela Manninen Turun yliopistosta kiteyttää.

Kirjoitus perustuu pidettyihin puheenvuoroihin ja käytyyn keskusteluun Politiikka-lehden järjestämässä etäjuhlassa "Valtio-opin vuosikymmenet - Tarinoita kuvien takaa" 14.10.2021.

\section{KIRJOITTAJATIEDOT}

\section{ANNU PERÄLÄ}

YTM, väitöskirjatutkija, toimitussihteeri

Vaasan yliopisto, Politiikka-lehti

annu.perala@uwasa.fi 